\title{
The Effect of Brief Cognitive Behavioural Therapy Group Intervention on Self Esteem among Drug Users
}

\author{
Huzilil Hussin ${ }^{1, *}$, M.H. Othman ${ }^{1}$, Kamarudin $\operatorname{Hussin}^{1}$ and N. S. Alias ${ }^{1}$ \\ ${ }^{1}$ School of Human Development and Technocomunication, Universiti Malaysia Perlis, Perlis, Malaysia
}

\begin{abstract}
Self-esteem is related to the individuals understanding and accepting the existing character and attitude to themselves. Failure to understand and accept their own strengths and weaknesses and in the same time do not have the skills to cope with it will caused them to be classified in the group who have low levels of self esteem. The up and down in self esteem will seriously affect the person emotional development and their reasoning process. Thus, reforming self esteem is an important key to help the rehabilition of drug abuser. Therefore, the purpose of this study is to investigate the effects of Brief Group Cognitive Behavioural Therapy on self-esteem among drug users. The quasi experimental design with one treatment group and one control group and four measurements (Pre Test, Post 1, Post 2 and Post 3) were employed in this study. The sample of 108 drugs users was chosen using purposive sampling procedure. Data were collected using standardized psychometric instruments, including Internal Control Index (Patricia Duttweiler, 1984) and The Rosenberg Self-Esteem Scale and were analysed using descriptive analysis. The findings shows the intervention of group Brief Cognitive Behavioural Therapy CBT (B) are succeed in increasing self-esteem mean score compared to control group in different time interval. As a conclusion, self-esteem among the subjects can be enhanced with an intervention of proper and systematic therapy instead of unplanned therapy sessions
\end{abstract}

\section{Introduction}

Self-esteem is how one views himself or herself in terms of self-value. It also concerns on how other people sees the values on him or her [1]. Proportionally, it is a selfbelief on oneself with self-worthy, self-respect and selfintegrity were one of the ingredients in enhancing or lowering one's self esteem [1]. Self-esteem involves on our feelings about ourselves and how we judge these feelings; either to be positive or negatives [2].

Thus, life experience plays important role in building and enhancing these positive and negative emotions [3]. The ups and downs of events that has happens in one's life have significantly contribute to the effect of how individual's sees themselves [1]. Individuals who were high in spirit and always vigilant in promoting positive emotions and thus positive self will always embrace high self-esteem no matter how the life's fluctuations are [3] however, to individuals who has low self-esteem, 'small fluctuations in life event' may mean like 'the whole deal of life' and significantly affect his or her emotions and personal values [1].

\subsection{Brief Cognitive Behavioural Therapy (CBT) on Drug Users}

Cognitive behavioural therapy is a talk therapy which focuses on current problems (Royal College of Psychiatrists). It gave insights on practical methods in improving the state of mind on daily problem basis without referring to the past events [4]. According to
Mahmood [5], CBT is counselling approach based on strategies to recognize, avoid and cope. CBT-based training skills focus on strategies to overcome the wants and the addictions by reinforcing motivation to change, to develop problem-solving skills, to design and to manage high-risk situations that may lead to return and also to develop skills to stay away from drugs.

The aimed of cognitive behavioural therapy is to make clients not to feel apprehensive and able to view current situation not to be stressful and non-threatening as negative stressors will heighten the negative emotions such as stress, anxiety, helplessness and depression [4]. These negative emotions will then lead to ineffective and less positive outcome of the counselling or therapy sessions between both parties [6].

Thus, according to McHugh et al. [7], cognitive brief therapy is the version of short-session that went up to ten or twenty counselling or therapy sessions. Cognitive brief therapy is much focused on specific issue or problem. Meaning that, in cognitive brief therapy the concept of current situation (here and there) was prioritized. The setting of goals and specific objectives in resolving, attending and helping the problem at hand was clearly overlaid and make known to both sides of the therapist and client. Subsequently, it is considered as on the most suitable and effective method in making change of behavioural problem [7]. Truth is the brief counselling has been practiced since 1949. Most counselling sessions in the year therapist in handling the issues of drug addiction [8].

* Corresponding author: huzili@unimap.edu.my 
Another supporting study which shows strong correlation on the use of cognitive brief therapy in enhancing self-esteem by looking at the self-efficacy of the drug addict was form [9]. Their study on 90 respondents of drug dependency patients shows significant improvement of coping strategy and significant reduction of addiction symptoms among the 90 drug addicts.

Additionally, study by Milan et al. [10] among 90 drug-dependent patients who were referring to the clinics in Uremia, Iran has also proven positive result in enhancing self-esteem by having the self-confidence (self-efficacy) in implementing and boosting coping strategies, the significant improvement of mental and physical health when using the cognitive brief therapy as a treatment.

\subsection{Problem in Self Esteem among Drug Users}

There were many studies shows on the causal factor of life's events that serves as environmental stressors for low self-esteem individuals with drug abused [11]. One of the study that was done by Wheeler (2010), involves on girls and drug abused. His study has shown the higher the self-esteem felt by the girls; the less drug abused were being practiced.

Another study that shows the influence of selfesteem and drug abused was from Khajehdalulee et al. [12], whereby their longitudinal study of one year from 2010 to 2011 concerning of 943 high school students from Sarakhs shows high significant correlation between self-esteem and drug abused for 507 of their respondents.

This study is parallel with a study by Stephens et al. [13] to 291 respondent of marijuana addicts. $87 \%$ of the respondents stated the reason of taking marijuana is because they have low self-esteem and 79\% reSDondents show low internal locus of controls. As the result, they will rely more on surrounding as well as fail to make a better path for their own life. Study by Fauziah et al. [14] shows that factor of low confidence contribute about $64 \%$ to repeated drug addicts.

Thus, an intervention that could help to improve their self-confident need to been implement to help drug addicts [14] to regain their self-esteem and self-control simultaneously.

\section{Research Methadology}

This study tests the effectiveness of Brief Cognitive Behavioural Therapy CBT[B] by using quasi experimental design with one treatment group [CBT (B)] and one control group (KW) and four measurements (pre, post 1 , post 2, and post 3 . The sample of 108 drug abusers was chosen using purposive sampling procedure. Samples were then distributed randomly into two groups: CBT (B) and control group (KW). Each group consisted of 36 samples. Data were collected with standardized psychometric instruments, including
Internal Control Index [15] and Rosenberg Self-Esteem Scale. Data were analyzed using Two-way ANOVA repeated measurement.

\section{Analysis on the Study}

In this study the effectiveness of the module are measured by the instruments and the results showed based on mean score, mean percentage and the change pattern of self esteem (SE) profil. Therefore, this section will present the results in mean score and standard deviation of self-esteem profiling for each groups CBT (B) and control group (CG) in each time occasion and the different of mean percentage between time occasions (Pre, Post Test 1, Post Test 2 and Post Test 3). Findings analysis for SE profile for group $\mathrm{CBT}(\mathrm{B})$ and $\mathrm{CG}$ between time occasions show in table below;

Table 1. Analysis findings of SE profile for group CBT (B) and $C G$ between time occasions

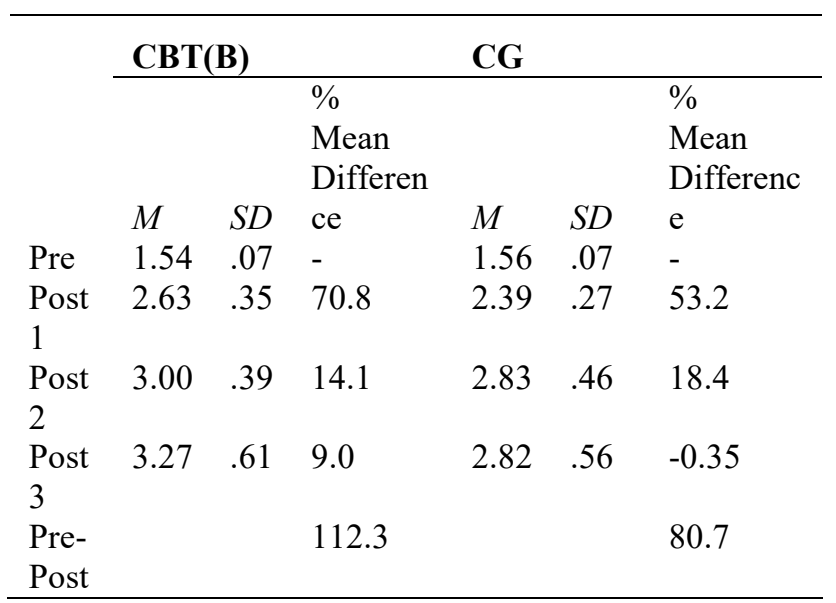

Result demonstrated SE mean score increased for group CBT(B) between time occasions from Pre Test $\mathrm{M}=1.54(\mathrm{SD}=.06)$, Post Test $1(\mathrm{M}=2.63 ; \mathrm{SD}=.35)$, Post Test $2(\mathrm{M}=3.00 ; \mathrm{SD}=.39)$ and Post Test $3(\mathrm{M}=3.27$; $\mathrm{SD}=.61)$. While the mean score percentage is $70.8 \%$ increase for Post Test 1 compare to Pre Test, $14.1 \%$ of mean percentage increase for different mean score for Post Test 2 and Post Test 1 and 9.0\% mean percentage increase for mean score for Post Test 3 compare to Post Test 2. Overally, $112.3 \%$ increase in mean score between Pre Test and Post Test 3.

While for control group (CG), result show the CG mean score for Pra test is $\mathrm{M}=1.56(\mathrm{SD}=.07)$, Post Test 1 $(\mathrm{M}=2.39 ; \mathrm{SD}=.27)$, Post Test $2(\mathrm{M}=2.83 ; \mathrm{SD}=.46)$ and Post Test $3(\mathrm{M}=2.82 ; \mathrm{SD}=.56)$. There are in mean score for group CG between time occasions. In the different of percentage for the mean score the mean score is increase by $53.2 \%$ in Post Test 1 compare to the mean in Pra Test, increase of $18.4 \%$ between mean in Post Test 2 and Post Test 1 and increase $-0.35 \%$ for mean score for Post Test 3 compared to Post Test 2. Overall, the increase is $80.7 \%$ between mean score percentage of pra test and Post Test 3. 


\section{Discussion}

The increases of SE mean score for treatment group CBT [B] might be because of the input in CBT module are applying skill of identifying characteristic of low self-esteem and how to increase it. In addition, the brief therapy also gives the skills to identify the health of client's emotions (healthy or unhealthy) and how to overcome the negative feelings. Skills to manage these emotions can help clients identifying internal problems, having the ability to think of themselves and more positively, and also achieving self-perfection [16].

Other than that, the improvement of SE is lead by the techniques of 'deserted island' and 'Socratic dialogue' implement to the clients. According to Beck [17], 'Socratic dialogue' help to answers a general questions asked by the clients along the sessions. While according to Curwen, B., Palmer, S. \& Ruddel, P. [18] 'deserted island' technique would help to change individual's internal belief to be freer and independence.

Curwen et al. [18] said, instead of changing ones character and personality, the CBT approach fosters individuals to be more responsible for their lives. According to Wilding et al. [19], CBT model is engaged to solve problems in daily life through training skills to increase the level of self-understanding and being responsible for themselves. The important thing is the individual trained to achieve balanced between thinking and behaviour. Thus, they will be able to identify the negative thought and change the negative to the positive behaviour. Moreover, approaches and techniques to control thinking and behaviour are different from detaining or restricting the thinking and the behaviour as they help towards self-understanding to build a better life. This means CBT approach will not only causes the clients to feel good and comfortable but they know more clearly why they feel good and comfortable.

Meanwhile, according to Mahmood [19], a role in rehabilitation counseling can help clients build a new, positive behaviour, develop problem-solving skills and potential, strengthen family relationships, increase selfesteem, self-awareness, positive thinking and help them to develop the independent attitudes. Meanwhile, according to Mahmood et.al [20], a role of counseling in rehabilitation is to help clients have a significant changes in a psychological aspects such as depression, anxiety, self-esteem and to increase self-esteem. Studies summarizes both group and individual counseling intervention can solve the problem of alcohol and drug addiction.

Based on Mior [20], he said that there is significance different between treatment groups which emphasize on therapeutic elements compared to control group which did not apply the therapeutic relationship. This is in line with study done by Schutte et al. which proves the effectiveness of CBT intervention in improving self-esteem of individuals who suffered from prolonged fatigue and also improving self-esteem of individuals who have self-image and self-concept problems [21].

Overally, this study shows that Brief Cognitive Behavioural Therapy Intervention is effective in improving self esteem of drug users compared with the control group that did not receive any treatments. We can conclude that with structured and systematic module and with the influence and cooperation by comitted, dedicated, skilled and experienced counselor can help to ensure the success of the intervention using CBT approach through group counseling methods for drug rehabiliton. It is clear from the results of this study, this module can be used as a reference for the development of experimental research in Malaysi and most important is it can also used as one of the approaches applied in all treatment procedures of drug rehabilitions in Malaysia.

\section{References}

1. Alavi, Hamid, Reza, Journal of Addiction and Health 3(3-4), 119-124 (2011)

2. H. Lotfabadi, Development Psychology: Adolescence, Young People and Adults (Tehran: Samt Press, 2009)

3. S. Kermode, D. MacLean, Aust J Adv Nurs 19(2). 33-40 (2001)

4. K. M. Carroll, S. A. Ball, C. Nich, P. G. O'Connor, D. A. Eagan, T. L. Frankforter, E. G. Triffleman J. Shi, B. J. Rounsaville, Arch Gen Psychiatry 58, 755-761 (2001)

5. Mahmood Nazar Mohamed (2003), Merawat Penagih Dadah Melalui Kaunseling dan Pendekatan Berperspektif Islam. Prosiding Seminar Kebangsaan Kaunseling Berperspektif Islam. Universiti Utara Malaysia.

6. K. M. Carroll, Therapy Manuals for Drug Addiction. Manual 1: A Cognitive-Behavioral Approach: Treating Cocaine Addiction (1998)

7. R. K. McHugh, B. A. Hearon, M. W. Otto, Psychiatric Clinics of North America 33(3), 511-525 (2010)

8. A. Molaie, S. Shahidi, S. Vazifeh, S. Bagherian, Journal of Social and Behavioural Sciences, Prodecia 5, 1180-1184 (2010)

9. H. Kamarzarrin, M. Khaledian, M. Shooshtari, Z. Ahmadimehr, Journal of Engineering and Applied Sciences 3(13), 1293-1300 (2013)

10. Milan, Hassan Brockie, Kamarzarrin, Hamid, Zare, Hossein, Journal of Research on Addiction Quaterly Journal of Drug Abuse (2014)

11. D.W. Brook, E. Rubenstone, C. Zhang, N.K. Morojele, J.S. Brook, Journal of Soc Sci Med. 72(9), 1447-1453 (2011)

12. Khajehdaluluee, Mohammad, Zavar, Abbas; Alidoust, Mahbobeh, Pourandi, Razieh, Journal of Iranian Red Crescent Medial Jounal 15(11), (2013). doi: 10.5812/ircmj.7682

13. R.S. Stephens, R.A. Roffman, L. Curtin, Journal of Consulting \& Clinical Psychology 68, 898-908 (2000)

14. Fauziah Ibrahim, Bahaman Abu Samah, Mansor Abu Talib, Mohd Shattar Sabran, Jurnal Antidadah Malaysia. Jld. 5, 235-251 (2009) 
15. P.C. Duttweiler, The Internal Control Index: A Newly Developed Measure of Locus of Control. Educational and Psychological Measurement 1984 44, 209 (1984) doi: $10.1177 / 0013164484442004$.

16. K.S. Dobson, Handbook of cognitivebehavioral therapies (New York: The Guilford Press, 2001)

17. J.S. Beck, Cognitive Behavior Therapy: Basics and beyond (New York: Guilford Press, 2011)

18. B. Curwen, S. Palmer, P. Ruddel, Brief cognitive Behaviour therapy (London: SAGE Publications, 2000)

19. Mahmood Nazar Mohamed, Mumulihkan Penagih Tegar : Implikasi kepada Modaliti Masa Kini. Prosiding Kerja Sosial (Universiti Utara Malaysia, 1991)

20. Mahmood Nazar Mohamaed, Md Shuaib Che Din, Lasimon Matokrem, Muhamad Dzahir kasa, Rusli Ahmad, Penagihan dadah dan residivisme: Aspek-aspek psikososial dan persekitaran (Sintok: Universiti Utara Malaysia, 1999)

21. S.H. Dworkin, B.A. Kerr, Journal of Counseling Psychology 34(2), 136-140 (1987) 